\title{
Using Social Media to Motivate Anti-migration Sentiments. Political Implications in the United States and Beyond
}

\author{
Blanca Nicasio-Varea \\ Universidad Cardenal Herrera-CEU, CEU Universities (Spain) \\ Marta Pérez-Gabaldón \\ Universidad Cardenal Herrera-CEU, CEU Universities (Spain) \\ Manuel Chavez \\ Michigan State University (USA)
}

The proliferation of nationalist and nativist movements all over the world has capitalized on the broad impact of social media, especially on Twitter. In the case of the United States, as candidate and then as President, Donald Trump initiated an active use of Twitter to disseminate his views on migration and migrants. This paper analyzes the themes and the political implications of his tweets from Trump's electoral win to the end of the first year of his presidency. The authors' assumptions are that Trump's rhetoric untapped a collective sentiment against migration as well as one which supported views to protect migrant communities. The findings show that some topics were retweeted massively fueling the perceptions that most Americans were against migrant communities and their protectors.

We conducted content analysis of the tweets sent by President Trump during his first year in the White House. We used the personal account of Trump in Twitter @realDonaldTrump. Trump has used his personal account as a policy and political media instrument to convey his messages rather than to use the official account that all Presidents have traditionally used @POTUS. Since Trump ran on a nativist platform with strong negative sentiments against migrants and immigration in general, we examined the tweets that relate to these topics.

Keywords: Trump, immigration, twitter, populism, social media, social networks. 

he use of social media by elected governmental officials have been more active in recent years when they post information, perspectives, or commentaries in the official account of their job. However, few have used their personal accounts to present their personal views or even policy standpoints and recommendations in Twitter, they do that because of the potentials for backfires and rapid attacks. However, Donald Trump stated that his use of social media was not "Presidential... it is Modern Day Presidential" (Trump, 2017). What the message meant is that he was willing to say anything and everything he wants that disrupt and break all historical presidential traditions. Many observers thought that his use of Twitter as candidate would change as soon as he would arrive to the White House, actually it got worse (Levistsky and Ziblatt, 2019; Kellner, 2016). False statements and incendiary rhetoric continue to be used by the President on almost any topics that called his attention.

One topic was particularly troublesome for many observers: his nativist approaches towards immigration (Pérez-Huber, 2016; Demata, 2017; Zhang, Robinson, and Tepper, 2018). From the time he announced his candidacy on July 15, 2015, Trump made clear that immigration was at the top of his political platform. He started by tagging Hispanics and Muslims as the causes for all the economic, social, and political problems of the US. Early in the campaign process it was notorious that Trump was willing to use disinformation and populists remarks that were insulting, demeaning, offensive, and plain discriminatory (Colley, 2019). His rhetoric took a tone that ignited a dormant anti-immigrant sentiment that had important biases, stereotypes, and racist attitudes; in other words, he was appealing to the nativists who wanted to keep the country as it was in the past (Oliver and Rahn, 2016; Khosravinik, 2017).

Immigration is a problem that America has faced since its founding, whether legal or illegal. Currently, the country has 44 million foreign born people or $13.6 \%$ of the total population of which 10.5 million are unauthorized migrants (Pew Research Center, 2019). The unauthorized population is composed by people from different nationalities, including Latin Americans, Asians and Europeans.

Trump stand on immigration was very clear. The country was being invaded by illegal migrants that were stealing jobs from Americans and those migrants were in the country to supply drugs, increase crime, and escalate sexual assaults (Flores and Chavez, 2020). Visible arrival of migrants from Latin American countries were targeted first. Then he turned his attacks to Muslim migrants who were in the country to commit terrorist attacks against Americans. He, in fact, was seeking to exacerbate the fears of white older Americans who did not want to see different people in their communities, ignoring the economic and demographic realities of the US. Ultimately, immigration was then a point of departure for Trump's political disruption of the 2016 presidential election.

During the presidential campaign, Trump confronted Clinton by stating that she intended to be soft on borders. The border wall was a campaign talking point to stop illegal immigration, and he made that clear in any speech opportunities but also in social media. The messages Trump crafted during the campaign were directed not only to attack Clinton about her softness on border and immigration issues, but also to rise more anti-migrant sentiments. 
Trump has used his personal Twitter account @realDonaldTrump to create a distorted frame of immigration by repeating continuing snippets that underlined the attacks and negative impacts of immigrants to the US. Twitter is able to post direct messages, then embed messages from other sources or redirect the reader to other websites or sources of information and it allows to share the tweet or to retweet the original message to other followers which creates an immediate viral tool. Due to Twitter is free, the cost for political candidates is literally insignificant, and the power to disseminate at not financial cost make it very attractive. In addition, Trump has been successful in bypassing journalists and the traditional media by claiming that Twitter is a tool to communicate directly with Americans (Jacobs, 2019: 82; Oh and Kumar, 2017: 11). Twitter, however, is not an editor that can change or correct erroneous information; in fact, Trump has not always been successful when he often asserts or provides false or inaccurate information.

Trump uses of Twitter are not divorced from his speeches and media interviews where he always expanded his tweets statements. The analysis of Trump's tweets shows that he writes the tweets with more "emotionally charged" words in them, such as "badly", "crazy", or "weak" regardless of who he is referring to. He is also less likely to use hashtags, photos or links in his tweets; in other words, he wants to establish his position as the only valid position in a discussion (Robinson, 2016).

The use of a tool that allow to disseminate any information regardless of its veracity is a megaphone for populists and Twitter has facilitated it (Lockhart, 2019). The rhetoric and the content can be outrageous and there would not be any filter between the politician who sends the message and the target audience. The framing and semantic writing in his tweets has been constantly repeating the same messages since his candidacy: immigration is the sole issue that explains all the failures of the US. As more populist his message became, Twitter is the powerful tool to attract audience and supporters, and when he fails to provide logical and cohesive policy information, he turns to his tweets to divert the attention or to attack the news media that put in evidence his errors (Colley, 2019).

\section{LITERATURE REVIEW}

Academic research has departed from a plurality of perspectives and debates to understand the contemporary use of the concept "populism" (Ribera y Díaz; 2020). Discussion is focused on three positions: populism as an ideology (Mudde, 2004), as a form of political mobilization, and as a discursive frame (Bonikowski, 2017: 184). In terms of this study, the last option is the correct theorical possition (Bonikowski, 2016; Aslanidis, 2016; Moffitt, 2016), because a frame is the way of presenting a message from a concret perspective in order to improve its impact on audience (Benford and Snow, 2000).

Populism usually surges associated with mass political movements of the late nineteenth and early twentieth centuries (Uribe, 2017). In the US, the origins of populism are confused with the birth of the Republic and Andrew Jackson the 
seventh President of the country (1829-1837) as his first proponent (Puértolas, 2017: 114). Currently, populism is an expanding political phenomenon (Wodak, 2015), and populists have disrupted long established patterns of party competition in many contemporary Western societies, in Europe and in America (Norris and Inglehart, 2018: 4). Its causes do not go back exclusively to the financial crisis of 2008, but

is part of a growing revolt against conventional politics and liberal values (Eatwell and Goodwin, 2019: 13).

In fact, populism is the symptom of the contingency of the relationship between a mass society and its political power and being able to adopt the most varied political aspects and figures (Villacañas, 2017: 17). Specifically, Brexit and Trump have proved to be the prelude to the greatest boom of extreme right-wing populism in Europe such as: Marie Le Pen in France, Matteo Salvini in Italy, Viktor Orban in Hungary and Santiago Abascal in Spain, among others.

However, it is important to keep in mind that these booming political phenomena are perceived as a new form of populism, in which the ideology loses weight in favor of the charismatic personality of the leader (Uribe, 2017: 216; Cossarini and Vallespín, 2019). This is because in their relationship with voters, their styles predominate more than the contribution of political content (Alonso and Casero, 2018). In this way, the strategy of spectacularizing politics tends to be accompanied by simplistic rhetoric (Ott, 2017), informal (Ahmadian, Azarshahi, and Paulhus, 2017) incendiary and provocative statements (Winberg, 2019), sometimes aggressive and insulting using resources such as irony and humor (Alonso and Casero, 2018: 1200).

Thus, the personality of the leader is characterized by a certain egocentrism that marks, without a doubt, his communicative style. In this sense, Trump can be seen as the most relevant example of this, by using the media as a tool to spread "his ideology" (Kreis, 2017: 608). In fact, since he announced his candidacy for the Republican nomination for the Presidency of the United States in 2015, he has regularly used his personal Twitter account to communicate his political agenda, an attitude he has maintained after his arrival at the White House. He is also framing his discourse on the so-called sharepolitica, or to communicate by generating trending topics (Carrillo, 2017: 137), and the typical approach using negative connotations (Gross and Johnson, 2016).

Given the above, we understand the reason why social networks have become a basic communication tool for Trump (Ott, 2017; Gerbaudo, 2018) due to its immediacy, its ability to spread the message and reach to the general public without any kind of barrier, its potential to mark the political agenda with its own issues, its power to bypass the traditional media, its ease of presenting itself as a framework for launching attacks on its political opponents, its perfect format for launching messages with a simple and direct arguments (Casero, Feenstra, and Tormey, 2016; Gross and Johnson, 2016; Galán, 2017) and, lastly, his unconventional, aggressive and offensive use of the social media (Wodak and Krzyżanowski, 2017). As a consequence of all this, using social media and networks is for those political figures, the favorite medium of propaganda. It is 
commonly assumed that the possibility of interaction with user-citizens favors

its use as a tool for political communication as a strategy to approach citizens, despite the fact that previous studies show that Trump does not usually interact with the rest of network users, using a top-down style (Kreis, 2017: 616). Despite this, one of the features that define populism is the struggle for the adherence and faithfulness to the masses (Villacañas, 2017: 18) and, to achieve this, populist leaders place special emphasis on ensuring proximity to the electorate through the use of social networks.

Trump's messages on Twitter presents two of the characteristics linked to the leader-followers relationship, as being characteristic of populist rhetoric, and that we will analyze in the following sections of research paper. First, he presents a strongly anti-establishment and anti-political discourse (Freidenberg, 2007: 245; Wodak, 2015, Norris and Inglehart, 2018) as he publicly questions the functioning and fulfillment of the functions of state institutions.

And secondly, it is observed that the discursive framework is established in terms of we-they or friend-enemy (Laclau, 2013) because

although such relationship does not necessarily have to be an antagonistic, there is always the possibility (...) This is the case when others, who until now had been considered simply as different, begin to be perceived as those who question our identity and threaten our existence (Mouffe, 2010).

In this sense, Trump uses Twitter to identify the enemy that he himself has generated and then places himself on the opposite side as a savior that will defeat it (Carrillo, 2017: 136). Thus, Trump has succeeded in harnessing and expanding the right-wing populist movement (Abromeit, 2018: 15). In the case of immigration, according to the results of previous studies, the US President uses the idea of the threat "to the people and the country" by illegal immigrants who take jobs from Americans, who are terrorists that threaten the American way of life, or take advantage of the social benefits of the American system (Kreis, 2017; Winberg, 2017; Wright and Esses, 2018). In fact, the 2016 presidential election witnessed a resurgence of American-style populism, bringing Trump to the White House on a wave of anti-immigrant and nationalist sentiment (Oliver and Rahn, 2016). With this speech he tries to generate an anti-immigration sentiment in Americans, appealing to the irrational and emotional part of citizenship (Demertzis, 2006; Rico, Guinjoan, and Anduiza, 2017). The consequences of this criminalization are the foundation of Trump's proposals for deportation of illegal immigrants, the proposal for a wall between the United States and Mexico and the negotiation or cancellation of the North American Free Trade Agreement (Carrasco-González, 2017).

\section{METHODOLOGY}

Based on the context explained in the previous section, the present research analyzes the messages published on Twitter by President Trump from his 
inauguration on January 20, 2017 until the end of his first year of office; that is, until January 20, 2018. The twitters were scrapped and collected by using the program Netlytic, downloaded to an Excel spreadsheet to be analyzed. The authors decided to focus mainly only the messages posted in Trump's private account@realDonaldTrump and not from the official account of the President labeled@POTUS.

The objective is to examine the use and management of Twitter social networking posts published in the personal profile of the President Trump during his first year in office. We analyzed the content of the messages - centered on the frames used, the main approaches and the value connotation towards immigrants in the United States. This is intended to identify, in quantitative terms, the impact of the messages and trends in the activity of the social network in relation to the purpose of the analysis and, in qualitative terms, their content based on a series of pre-established variables. Likewise, it is intended to identify citizen responses.

To meet the objective set by this research, the following research questions are formulated:

1. RQ1. What are the migration salient areas of President Trump tweets in his first year?

2. RQ2. What are the main targets of President Trump tweets in his first year related to migration?

3. RQ3. What general frames were used more frequently by President Trump in his first year?

4. RQ4. How did President Trump frame migration in his tweets during the first year?

5. RQ5. What is the degree of dissemination of the messages related to immigration that President Trump posted in his first year in office?

To answer the proposed research questions, the sample was extracted using the program Netlytic, in order to select all those Twitts posted by President Trump during his first year of mandate related to immigration policy. To carry out the search, the following keywords were used: travel ban, immigration, immigrants, DACA and illegal immigration. Data concentrates fundamentally on tweets posted in Trump's personal account and the retweets, favorites and comments from those posts were included in the sample. The total number of sampled tweets was 38 tweets. Each tweet served as the unit of analysis.

Once the sample was obtained, the study of the tweets was carried out on two levels, one quantitative and the other qualitative. For the quantitative analysis, the total number of tweets and retweets has been compiled and accounted for manually in the period indicated above, recording the total number of retweets, the total number of likes and the total number of comments.

For the qualitative study of the messages content posted on the President Trump personal account, a triple analysis has been carried out. The first one relates to identifying the predominant frame in the discourse of each tweet, the following variables being used: 
1. Criticism of Democrats. It refers to messages with critical, derogatory or negative content about the work of the Democrats in relation to immigration policy.

2. Defense of travel ban. It contains messages of support for the President's proposal to toughen the entry of immigrants into the country through legislation.

3. Support for Trump's immigration policy. It contains messages that, in general, refer to the different measures that the President proposes to control migratory movements in the country.

4. Criticism of Congress. It refers to the messages in which, directly, the President questions or accuses the Congress for the neglect, slowness or laxity of the legislation on migration matters, specifically in relation to the protection of migrants who entered illegally in the country as minors (DACA).

5. Criticism of the judiciary. It contains messages in which the President questions the work of the judiciary in cases related to immigrants.

6. Criticism of the previous immigration policy. It includes the messages in which Trump launches generic criticism of the immigration policy of previous Presidents and how this is the cause of the current problems of insecurity associated with the number of illegal immigrants in the country.

From of all these variables, one is indicated after the complete reading of the message so that these are exclusionary variables.

The second analysis deepens on the approach adopted in the message, which may be positive, negative or neutral. In any case, one is signaled after the complete reading of the message so that these are exclusionary variables.

The third and final qualitative analysis deepens the assessment that the President makes in his messages, implicitly or explicitly, about immigrants. In this case, according to previous studies of Trump's speeches on immigration, they are based on the repetition of negative topics about it (Carrasco-González, 2017; Green, 2016; Wright and Esses, 2019). We established the following categorization: illegal, generating insecurity, criminals, dangerous, system abuser, rapists, and drug dealers. Although methodologically will be pointed out the variable with the greatest weight or most significant in the message in exclusionary terms, it is expected that several of them may appear over imposed, albeit on a secondary basis in the same message.

\section{FINDINGS}

Related to RQ1, it is observable that Trump tweets have a tendency to use qualifiers, either explicit or implicit, with a high pejorative load. As can be seen in Figure 1, only $18 \%$ of published tweets do not perform any type of negative assessment regarding immigrants. Thus, the majority or $82 \%$ of the messages published in the social network contain a critical attack against this sector of the population, considering them specifically the origin of insecurity in the United States (32\%), 
58 and underlining their status as illegal (24\%). Without abandoning these two variables that are at the bottom of all the messages published on Trump's tweets, $10 \%$ of the messages focus the discourse on the consideration of immigrants as "criminals", while 8\% on their condition of "dangerous" subjects and another $8 \%$ focuses attention on how immigrants benefit either from previous migration policies, or from the provision of social services provided by the state.

Figure 1. Main Themes related to immigration messages posted by Trump on his personal Twitter account during his first year in the Presidency

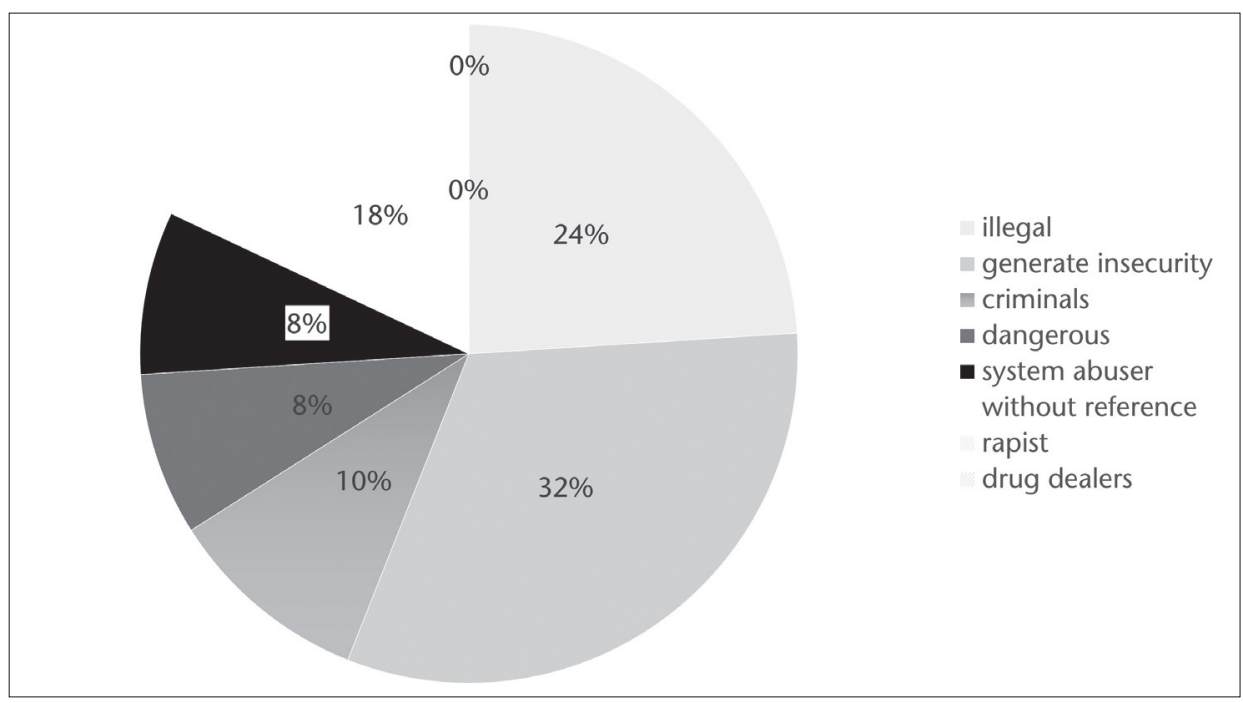

Source: Data extracted from Twitter and calculated by the authors.

In connection with RQ2, Trump's speech on social networks regarding United States immigration policy during his first year of office is essentially aimed at the general public (69\%). This is so in order to persuade and convince US citizens of both the damages from the current immigration policy which was there prior to his arrival to the White House, as well as persuading them of the benefits derived from applying the changes he proposed on that policy. In addition, it is inferred a willingness to convey stereotyped and negative visions of immigrants by making generic and categorical statements about how they are a scourge that makes difficult to implement his slogan "Make America Great Again". It cannot be forgotten that this slogan is exclusionary because it leaves out all those citizens who, even though they are American citizens, are not part of the White majority. 
Figure 2. Main political objective of each tweet posted by Trump during his first year in office related to immigration

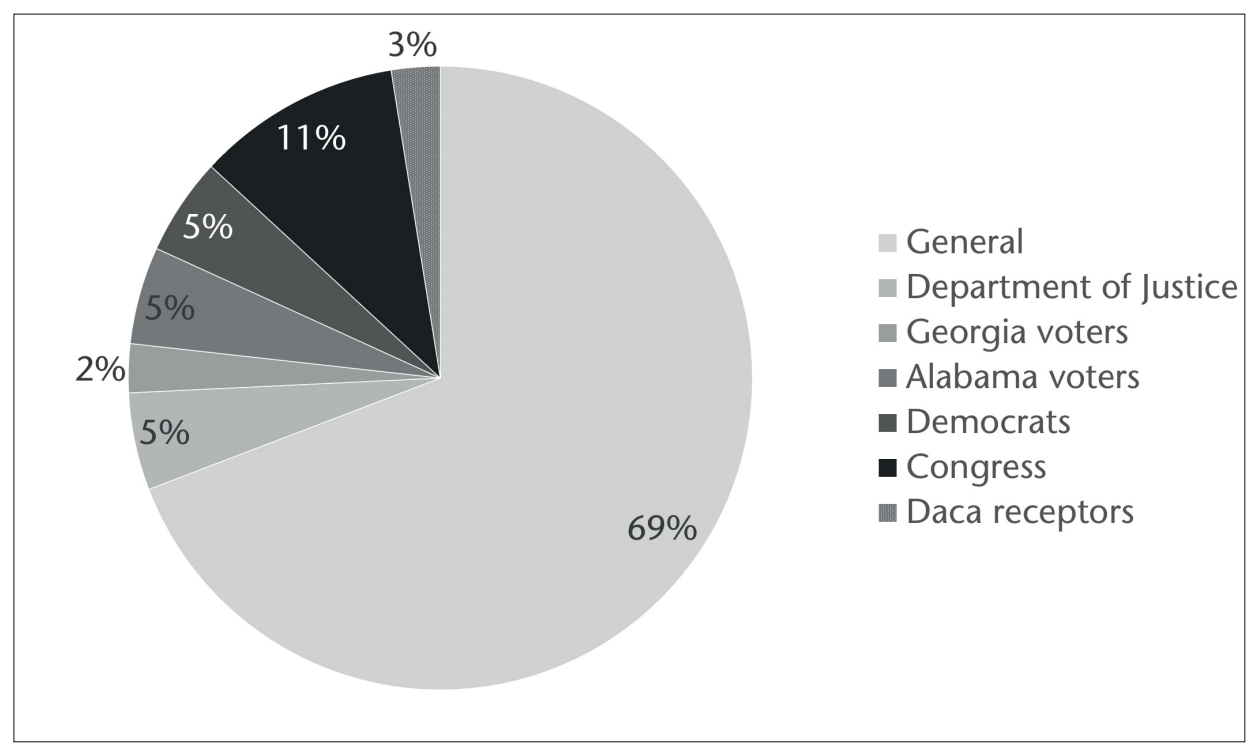

Source: Data extracted from Twitter and calculated by the authors.

Even though most of its messages of political propaganda are general, there is a tendency to directly challenge both the other powers of the state and the Democratic Party opposition. This is so because, on the one hand, the tweets launch direct criticism to both Congress, by demanding more restrictive legislative action about immigration and DACA policies (11\%), as well as to the Department of Justice when the messages question its work in relation to immigrants (5\%). On the other hand, Trump refers to the Democrats as the cause of the delay in moving towards the materialization of the immigration policy proposed by him $(5 \%)$

Concerning RQ3, there is a clear tendency to issue critical messages on immigration in Trump's tweets posted during his first year in office. Only 34\% of the tweets had a non-critical vision and focused on defending the President's immigration policy, on general topics were minimum (8\%), but they increased particularly about the travel ban (26\%) (see Image 1). 


The $\begin{aligned} & \text { Donald J. Trump } \\ & \text { @realDonaldTrump }\end{aligned}$
That's right, we need a TRAVEL BAN for
certain DANGEROUS countries, not some
politically correct term that won't help us
protect our people!
6/5/17, 21:20

Source: Twitter.

On the other hand, the other $66 \%$ of the messages have a clear critical tone. Certainly, this pattern fits the trend at all levels of the personal profile of Trump. Studies show the tendency towards a populist, aggressive and unsubstantiated discourse as the essential bases of its communication strategy in social networks. Thus, in the case of messages relating to the immigration issue published during his first year of office, it is observed how the President follows that same pattern. The main objective of their criticisms is the Democrats (47\%) who he blames about the immigration problem and described as inefficient not only in legislative work but also on passing it. Similarly, Trump tends to criticize immigration policy not only from the Obama Administration, but about the immigration policy of the last 45 years based on the lack of control over the entry of "illegal" immigrants and their permanence in the country (3\%). The other main focus of his criticisms is about the legislative branch (3\%) and the judicial branch (13\%), since he considers that they have not exercised optimally their constitutional functions regarding immigration issues.

Figure 3. Frames most frequently used by Trump tweets related to immigration during his first year in office

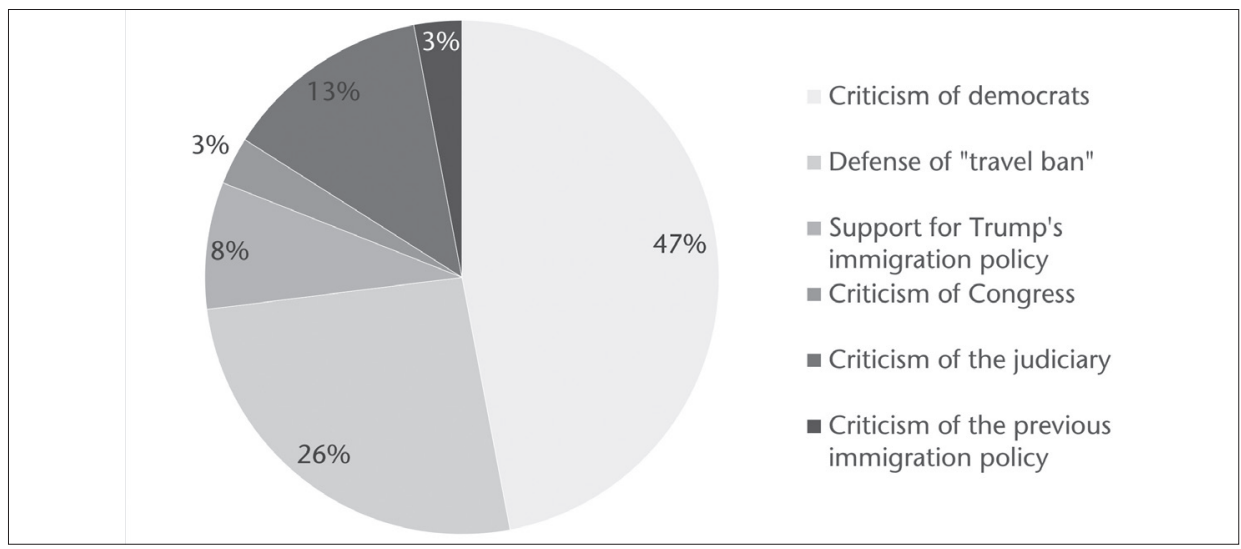


Similar to previous studies (Levistsky and Ziblatt, 2019; Kellner, 2016, Ott, 2017;

Lee and $\mathrm{Xu}, 2018$ ) that describe Trump's speech as negative, demagogue, populist and tending towards humiliation, the analysis of the tweets in this study show, regarding RQ4, that they followed that same pattern. Thus, in particular, it is observed that more than $60 \%$ of the messages posted show a clearly negative tone and approach, that is, Trump uses qualifiers, assessments and statements aimed at blaming immigrants for the problems of insecurity, danger and criminality across the country (see Image 2).

\section{Image 2. Trump's tweets showing his negative approach}

(21) Donald J. Trump
बrealDonaldTrump
The weak illegal immigration policies of the
Obama Admin. allowed bad MS 13 gangs to
form in cities across U.S. We are removing them
fast!

Source: Twitter.

By contrast, only $19 \%$ of the messages published during that first year are positive, while $18 \%$ maintain a neutral tone. Among the former, those oriented to praise, recognize and promote the initiatives and actions taken by the President about the containment of immigrants' arrival to the country, as well as the deportation of those who reside illegally in the United States. Among the latter, are those tweets that intend to encourage progress in the regulation of travel ban.

Figure 4. Focus (positive, negative or neutral) of the tweets posted by Trump during his first year in office

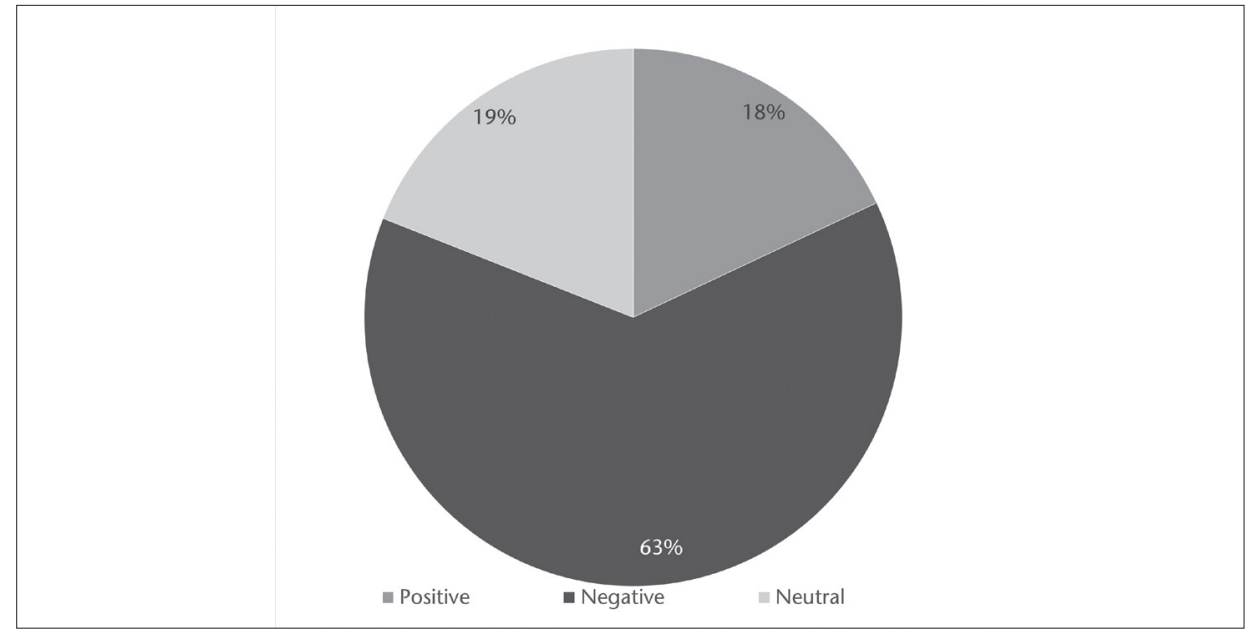


One of the issues that most researchers have studied so far is, not only the populist nature of the messages published in Trump's personal profile, but also the citizen's response to them as a sign of the impact of those messages. In other words, and linked to RQ5, do the tweets have audience?

Table 1. Total number of likes, comments and retweets in the messages on the immigration issue, published by Trump

\begin{tabular}{l|l|l}
$\begin{array}{l}\text { Number of } \\
\text { Comments }\end{array}$ & $\begin{array}{l}\text { Number of } \\
\text { Retweets }\end{array}$ & $\begin{array}{l}\text { Number of } \\
\text { Likes }\end{array}$ \\
\hline Total: 106,3300 & Total: 834,018 & Total: $3,549,374$ \\
\hline Mean per post:27.981 & Mean per post: 21.947 & Mean per post: 93.404 \\
\hline
\end{tabular}

Source: Data extracted from Twitter and calculated by the authors.

In the case of tweets posted during the first year of Trump on immigration issues, a high level of interaction by citizens or supporters is observed. In fact, each and every one of the tweets analyzed have a significant number of comments, retweets and likes. Among these three options, mostly citizens have opted for the resource they "like", so each of the tweets has an average of 93,404 "likes". The second most used resource is the one that requires more effort and involvement from the user, that is, the comment, with an average of 27,981 comments per tweet. This is because one must spend time preparing your own argument to respond to the posted message. These numerous comments were positioned both in favor and against what the President posted, some of them well argued while others were limited to show their position of agreement or disagreement without further deepening on the issue. Ultimately, users have resorted to the retweet, with an average of 21,947 per each post.

Certainly, the retweet is the one that facilitates the dissemination of the published message since it will appear on as many walls as people have resorted to it, thus reaching all the followers of that person. However, the other two ways do not guarantee the dissemination of this message through the profiles of the followers who have resorted to interact with him.

\section{DISCUSSION AND CONCLUSIONS}

Following the analysis of messages posted by Trump on his personal Twitter account during his first year in office, regarding immigration issues, a strategy is noted of direct, populist, aggressive, stigmatizing and critical communication. So, the results of the present research agree with previous studies that have analyzed in-depth Trump's communication in digital environments (Kellner, 2016; Wodak and Krzyżanowski, 2017; Norris and Inglehart, 2018). These studies have placed special emphasis on the demagogue, populist and humiliating tone as a characteristic element of how he presents his political messages in his private Twitter account. 
Based the data analysis, the results of the present investigation yield the following conclusions. The first conclusion shows that the vast majority of messages published contain significant critical attacks directed to immigrant groups. That is, more than $80 \%$ of the messages on migration issues posted during the review period, focus the discourse on qualifying pejoratively this sector of population. It can be understood that this discursive tendency is aimed at generating, reinforcing and strengthening the image of immigrants as an illegal, dangerous and criminal collective, in order to convince the population of the need to tighten immigration policy -that he proposes. Messages emphasize the creation of a discourse of fear and insecurity that contributes to achieve his political objectives.

The political strategy of the discourse of fear has been widely studied as the basis of political communication of both political leaders and formations close to populism (Frei and Kaltwasser, 2008; Wodak, 2015; Nai, 2018). This strategy tends to simplify the message in terms of we versus them and of friends versus enemies, because the content of the message can give an easily understandable and assimilable explanation to the public. In other words, the strategy "helps" the positioning of the population in one of the two groups, and establish frames (Lakoff, 2004) that mark the political and media agenda. It should be noted that

the permanence of populism depends on its constant ability to activate collective passions. For this, he resorts to the exploitation of emotional attention niches, such as speeches and images that arouse emotions such as indignation, fear and hatred in order to keep alive the distinction between friend and enemy in society (Frei and Kaltwasser, 2008: 133).

The second conclusion reflects how the target audience serves also the wide reach of Twitter messages dissemination. Thus, $69 \%$ of the messages are intended to convince US citizens of the need to make immigration reform aimed at limiting the arrival of immigrants in order to increase national security, which would enhance the achievement of his campaign slogan of: Make America Great Again. This motto, which is exclusionary of the minorities living in the country, is an unequivocal sign of a policy that puts the focus of much of the blame for the problems of Americans on the presence of illegal immigrants, typical of the populist discourse (Oliver and Rahn, 2016). Posts are intended to his supporters, as well as to those who receive them because of the reach provided by social network dissemination, and they turn into direct transmitters of the message.

Another of the essential elements in his Twitter communication strategy, helps the third conclusion because it reflects how the vast majority of messages posted by Trump adopt a critical tone. In this sense, according to previous studies that demonstrate the tendency to use aggressive and unsubstantiated discourse (Gross and Johnson, 2016; Winberg, 2017), our results reinforce these findings since $66 \%$ of the messages provide some kind of criticism that, in turn, is usually little argued. While it is true that the 240 characters provided by the social network make it difficult to generate deep and biased arguments, it is no less true that the strategy followed by Trump tends to intimidate those arguments that go 
64 beyond the formulation of topics and superficial stereotypes, sign of a populist frame (Ott, 2017).

In fact, it should be noted that Trump adopts a communicative pattern more focused on criticism than on the defense and promotion of his immigration reform (which required Congress approval), either by stating what he intends to do or by overstating the benefits of his new immigration policy (migration laws enforcement). This is a model of communication strategy based on emotions - and not on rational way of thinking - that as indicated above, is leading to the generation of a good number of academic research on populism in the US.

In analyzing the criticisms expressed by the President, it is possible to observe two major foci: the first one has relevant actors as protagonists in the development and implementation of migration policy (Congress, the judiciary and the Democrats); the second is aimed at immigration policy prior to his arrival at the White House. Thus, from his private account, the President chooses to question the work of the other two branches of power, attacking the fundamental principle of the constitutionally recognized by the division of branches. Anti-establishment discourse has been widely studied by populism researchers (Wodak, 2015, Norris and Inglehart, 2018).

The previous arguments only permeates the main focus of the message content. Thus, the fourth conclusion shows that $63 \%$ of the messages adopt a clearly negative approach. The negativity of the messages, typical of the populist discourse followed by Trump, moves his political communication away from the space for resolving social conflicts (Mendé and Smith, 1999).

Finally, regarding the political interaction with citizens, the high degree of involvement of citizens can be underlined through the mechanics and benefits provided by Twitter. The fifth conclusion reflects how citizens adopt a proactive role in response to messages on the immigration issues posted by Trump during their first year in office, either to show their agreement and support, or to show their disagreement and rejection. Specifically, it is important to underline that the majority of followers use "likes" as a resource to interact with the President, implying in this way a favorable position for Trump's message content. After the likes, the second most used resource is comments. Although it is true that "comments" requires a greater involvement because it requires the elaboration of an argument, it should be noted that it is the instrument that most easily allows to show the disagreement with the message content. Finally, the "retweet" is used as a mechanism that allows the wide dissemination of the content of the message, making it possible to reach even non-followers who may have totally opposed political views. However, to this expansive effect of the message, it contributes indirectly to the reporting by traditional media of much of the rude and crude messages that Trump posts.

And yet, the possession of social network tools facilitates that the citizen can interact with the politician and show his position with less or greater effort, which leads to modify the traditional pattern of unidirectional communication between the politician and the citizen. This allows, a priori, the generation of a virtual two-way communication, which facilitates the political communication and provides a feeling of greater proximity between elected officials and voters. 
Some of the limitations of the present study need to be underlined. First, the limits that can be understood based on the sample selection. This is because we have used a series of keywords, and we may have missed some messages related to immigration issues posted in the period under analysis in Trump's private account on Twitter. This, which does not detract from the validity of the investigation, has been attempted to alleviate using not only the most recurring terms but also a large number. In turn, other terms have been used close to our objective which did not provide valid messages for the study.

Secondly, the first year in office has been set as a timeframe in response to the political relevance of immigration during that period. We understood that the framework could have been limited to the first 100 days in office - a reality that would have resulted in a very small and insignificant sample- or in the middle of the mandate - which would have led to a dilution of the packaging of the issue in the political debate. In any case, by limiting the first year in office, guarantees a sufficiently large time to observe generic guidelines in the communicative strategy used by Trump.

Lastly, the absence of a framework can be considered as a limitation compared to other issues on the American political agenda. While it is true that this could have yielded a more complete scenario about political communication on the President's Twitter use, it is no less true that this can be alleviated by going to other recent research on the topic. The present investigation brings light to the analysis of the imprint in the political communication of Trump in new social networks settings. Specifically, our research tries to contribute to the literature on the subject through an analysis of qualitative and quantitative content of a politically controversial issue such as immigration issues and policy. Certainly, these results are the first step in a broader investigation that seeks to examine the Trump's migration political discourse and its effects on American society and beyond.

Blanca Nicasio-Varea (blanca.nicasio@ uchceu.es) is graduated in Political and Public Administration Sciences (2010), and in Journalism (2009). Moreover, she holds a PhD (2017) cum laude, in Political Science, from the University CEU-Cardenal Herrera. She has received for her $\mathrm{PhD}$ the mention of European Doctor. Currently, she is a professor

\section{Marta Pérez-Gabaldón (marta.perez@} uchceu.es) holds a BA in Political Science and Public Administration (CEU Cardenal Herrera University, 2008), with Extraordinary Prize of Degree, and a PhD in Political of Electoral Systems and Political and Electoral Behaviour at the Cardenal Herrera University CEU. She has published several book chapters and articles on these topics. Previously, she has worked as a parliamentary advisor at Les Corts Valencianes and as an accredited parliamentary assistant in the European Parliament.

Science (CEU Cardenal Herrera University, 2012), with Extraordinary Prize of Doctorate. She also holds a BA in Law (UNED, 2018). Up to now, her main research areas have been: intergovernmental relations, climate 
change policies, transparency and political communication. Since 2008, she has participated in several public and private research projects and she has published two monographs and a significative number

Manuel Chavez (chavezm1@msu.edu) is a Professor of international and crisis journalism at the School of Journalism in Michigan State University. He teaches courses on the sociology of the media, international issues, journalism research methods, media law and ethics, crisis and the press. His recent research has concentrated on media reporting on issues related to the North American borders, environmental issues and journalism response to natural disasters and crisis. Dr. Chavez of book chapters and papers in specialized journals on those topics. She is University Lecturer, since 2011, and Academic Secretary of the Faculty of Law, Business and Political Science at CEU-Cardenal Herrera University.

has published several books and articles on these topics in addition to themes related to the Americas development and trade, cross-cultural communication, international communication, public diplomacy and migration and cross-border issues. $\mathrm{He}$ directs the International Collaboratory on Crisis Communication that includes 12 international universities. He serves as President of the Association for Latino Media and Markets Research Scholars.

\section{References}

Abromeit, John (2018). "Frankfurt School Critical Theory and the Persistence of Authoritarian Populism in the United States". In: Morelock, Jeremiah (ed.). Critical Theory and Authoritarian Populism. London: University of Westminster Press, pp. 1-27.

Ahmadian, Sara; Azarshahi, Sara and Paulhus, Delroy (2017). "Explaining Donald Trump via Communication Style: Grandiosity, Informality, and Dynamism". Personality and Individual Differences, 107, pp. 49-53.

Alonso, Laura and Casero, Andreu (2018). “Comunicación de los líderes populistas europeos en Twitter: Construcción de la agenda y efecto "más es menos". El Profesional de la Información, 27(6), pp. 1193-1202.

Aslanidis, Paris (2016). "Is Populism an Ideology? A Refutation and a New Perspective". Political Studies, 64(1), pp. 88-104.

Benford, Robert D. and Snow, David A. (2000). "Framing Processes and Social Move- ments: An Overview and Assessment". Annual Review of Sociology, 26, pp. 614-622.

Bonikowski, Bart (2016). "Three Lessons of Contemporary Populism in Europe and the United States". Brown Journal of World Affairs, 23(1), pp. 9-24.

-. (2017). "Ethno-nationalist Populism and the Mobilization of Collective Resentment". The British Journal of Sociology, 68, pp. 181-213.

Carrasco-González, Gonzalo (2017). “La política migratoria de Donald Trump". Alegatos, 95, pp. 171-194.

Carrillo, Francisco (2017). "El relato del miedo: La construcción del discurso en contra". In: Carrillo, Francisco (coord.). El porqué de los populismos. Un análisis del auge populista de derecha e izquierda a ambos lados del Atlántico. Barcelona: Deusto, pp. 135-162.

Casero, Andreu; Feenstra, Ramón and Tormey, Simon (2016). "Old and New Media Lo- 
gics in an Electoral Campaign: The Case of Podemos and the Two-way Street Mediatization of Politics". The International Journal of Press/ Politics, 21(3), pp. 378-397.

Colley, Dawn F. (2019). "Of Twit-Storms and Demagogues: Trump, Illusory Truths of Patriotism and the Language of the Twittersphere". In: Lockhart, Michele (ed.). President Trump and His Political Discourse. Ramifications of Rhetoric via Twitter. New York: Routledge, pp. 33-51.

Cossarini, Paolo and Vallespín, Fernando (eds.) (2019). Populism and Passions: Democratic Legitimacy After Austerity. New York: Routledge.

Demata, Massimiliano (2017). "A Great and Beautiful Wall. Donald Trump's Populist Discourse on Immigration". Journal of Language Aggression and Conflict, 5(2), pp. 274-294.

Demertzis, Nicolas (2006). "Emotions and Populism". In: Clarke, Simon; Hoggett, Paul, and Thompson, Simon (eds.). Emotion, Politics and Society. London: Palgrave Macmillan, pp. 103-122.

Eatwell, Roger and Goodwin, Matthew (2017). Nacionalpopulismo. Por qué está triunfando y de qué forma es un reto para la democracia. Barcelona: Ediciones Península.

Flores, María and Chavez, Manuel (2020). "Donald Trump US-Mexico Border Agenda: An Agenda-Building Examination of CandidateGenerated Messages". NorteAmérica, 15 (1), pp. 1-38.

Frei, Raimundo and Kaltwasser, Cristóbal (2008). "El populismo como experimento político: Historia y teoría política de una ambivalencia". Revista de Sociología, 22, pp. 117-140.

Freidenberg, Flavia (2007). La tentación populista. Madrid: Síntesis.

Galán, María (2017). “The 2016 Republican Primary Campaign on Twitter: Issues and Ideological Positioning for the Profiles of Ben Carson, Ted Cruz, Marco Rubio, and Donald Trump". El Profesional de la Información, 26(5), pp. $850-858$.
Gerbaudo, Paolo (2018). "Social Media and Populism: An Elective Affinity?". Media Culture \& Society, 40(5), pp. 745-753.

Green, David (2016). "The Trump Hypothesis: Testing Immigrant Populations As a Determinant of Violent and Drug-Related Crime in the United States". Social Science Quarter$l y, 97(3)$, pp. 506-524.

Gross, Justin and Johnson, Kaylee (2016). "Twitter Taunts and Tirades: Negative Campaigning in the Age of Trump". Political Science \& Politics, 49(4), pp. 748-754.

Huber, Lindsay (2016). "Make America Great Again: Donald Trump, Racist Nativism and the Virulent Adherence to White Supremacy Amid US Demographic Change". Charleston Law Review, 10, pp. 215-248.

Jacobs, R. N. (2019). "Journalism after Trump". In: Mast, Jason and Jeffrey, Alexander (eds.). Politics of Meaning / Meaning of Politics. London: Palgrave Macmillan, pp. 75-93.

Jeremiah, Morelock (ed.) (2018). Critical Theory and Authoritarian Populism. London: University of Westminster Press.

Khosravinik, Majid (2017). "Right Wing Populism in the West: Social Media Discourse and Echo Chambers". Insight Turkey, 19(3), pp. 53-68.

Kreis, Ramona (2017). "The Tweet Politics of President Trump". Journal of Language and Politics, 16(4), pp. 607-618.

Kellner, Douglas (2016). American Nightmare. Donald Trump, Media Spectacle and Authoritarian Populism. Boston: Sense Publishers.

Laclau, Ernesto (2013). La razón populista. Madrid: Fondo de Cultura Económica de España.

Lakoff, George (2004). Don't Think of an Elephant: Know Your Values and Frame the Debate. Vermont: Chelsea Green Publishing.

Lee, Jayeon and $\mathrm{Xu}$, Weiai (2018). "The More Attacks, the More Retweets: Trump's and Clinton's Agenda Setting on Twitter". Public Relations Review, 44(2), pp. 201-213. 
Levistsky, Steven and Ziblatt, Daniel (2019). How Democracies Die. New York: Penguin Books.

Lockhart, Michele (ed.) (2019). President Trump and His Political Discourse. Ramifications of Rhetoric via Twitter. New York: Routledge.

Mendé, María Belén and Smith, Cintia (1999). "La comunicación política: Un espacio de confrontación". Comunicar, 13, pp. 201208.

Moffitt, Benjamin (2016). The Global Rise of Populism: Performance, Political Style, and Representation. Stanford: Stanford University Press.

Mouffe, C. (2010). "Agonistic Politics in a Multipolar World". Documentos CIDOB. Dinámicas Interculturales, no. 15. Available at: $<$ https://www.files.ethz.ch/isn/115625/doc dinamicas_15.pdf $>$. Accessed 1 March 2020

Mudde, Cas (2004). "The Populist Zeitgeist". Government and Opposition: An International Journal of Comparative Politics, 39 (4), pp. 541-563.

Nai, Alessandro (2018). "Fear and Loathing in Populist Campaigns? Comparing the Communication Style of Populists and Non-populists in Elections Worldwide". Journal of Political Marketing, pp. 1-32.

Norris, Pippa and Inglehart, Ronald (2018). Cultural Backlash Trump, Brexit, and the Rise of Authoritarian Populism. New York: Cambridge University Press.

Oh, Chong and Kumar, Savan (2017). "How Trump Won: The Role of Social Media Sentiment in Political Elections". Presented at PACIS 2017 Proceedings, 48. Langkawi, 16-20 July.

Oliver, Eric and Rahn, Wendy (2016). "Rise of the Trumpenvolk: Populism in the 2016 Election". The Annals of the American Academy of Political and Social Science, 667(1), pp. 189-206.

Ott, Brian L. (2017). "The Age of Twitter: Donald J. Trump and the Politics of Debasement". Critical Studies in Media Communication, 34(1), pp. 59-68.
Pérez-Huber, Lindsay (2016). "Make America Great Again!: Donald Trump, Racist Nativism, and the Virulent Adherence to White Supremacy Amid US Demographic Change". Charleston Law Review, 10, pp. 215-248.

Pew Research Center (2017). "Key Facts about Unauthorized Immigrants Enrolled in DACA". Reported dated Sept. 25, 2017. Available at: <https://www.pewresearch.org/ fact-tank/2017/09/25/key-facts-aboutunauthorized-immigrants-enrolled-in-daca/>. Accessed 2 March 2020.

-. (2019). "Facts on US Immigrants". Available at: <https://www.pewresearch. org/hispanic/2019/06/03/facts-on-u-s-immigrants/>. Accessed 1 March 2020.

Puértolas, Juan (2017). "Donald Trump: El populismo conquista la Casa Blanca". In: Carrillo, Francisco (coord.). El porqué de los populismos. Un análisis del auge populista de derecha e izquierda a ambos lados del Atlántico. Barcelona: Deusto, pp. 113-131.

Ribera, Pablo and Díaz, José I. (2020). "Framing Populism in France Through the 2017 Presidential Election Speeches by the Leading Candidates". Revista Española de Ciencia Política, 52, pp. 13-36.

Rico, Guillermo; Guinjoan, Marc, and Anduiza, Eva (2017). “The Emotional Underpinnings of Populism: How Anger and Fear Affect Populist Attitudes". Swiss Political Science Review, 23(4), pp. 444-461.

Robinson, David (2016). "Text Analysis of Trump's Tweets Confirms He Writes Only the (angrier) Android Half". Variance Explained. Available at: <http://varianceexplained.org/r/ trump-tweets/>. Accessed 13 September 2018.

Trump, Donald J. (2017) Tweet posted on July 1, 2017 on his @realDonaldTrump Twitter account.

Uribe, Ainhoa (2017). "El populismo como vanguardia del desencanto político en Europa: El fenómeno 'Podemos' en España”. Revista de Estudios Políticos, 177, pp. 213-255. 
Villacañas, José Luis (2017). "La reinvención de la política. Orígenes y fundamentos del populismo contemporáneo". In: Carrillo, Francisco (coord.). El porqué de los populismos. Un análisis del auge populista de derecha e izquierda a ambos lados del Atlántico. Barcelona: Deusto, pp. 17-46.

Winberg, Oscar (2017). "Insult Politics: Donald Trump, Right-Wing Populism, and Incendiary Language". European Journal of American Studies, 12(2), document 4. Available at: $<$ http://journals.openedition.org/ejas/12132>.

Wodak, Ruth (2015). The Politics of Fear: What Right-wing Populist Discourses Mean. London: Sage.

Wodak, Ruth and Krzyżanowski, Michal (2017). "Right-wing Populism in Europe and
USA: Contesting Politics and Discourse Beyond Orbanism and Trumpism". Journal of Language and Politics, 16(4), pp. 471-484.

Wright, Joshua and Esses, Victoria M. (2019). 'It's Security, Stupid! Voters' Perceptions of Immigrants As a Security Risk Predicted Support for Donald Trump in the 2016 US Presidential Election". Journal of Applied Social Psichology, 49(1), pp. 36-49.

Zhang, Ziqui; Robinson, David, and Tepper, Jonathan (2018). "Detecting Hate Speech Detection Using a ConvolutionLSTM Based Deep Neutral Network" In: Gangemi, Aldo [et al.] (eds.). The Semantic Web. 15th International Conference, ESWC 2018. Springer International Publishing, pp. 745760. 